\title{
Using Thinking Maps in the Treatment of EFL Grammar Difficulties for Preparatory Stage Pupils
}

\author{
A Study Prepared by \\ Hisham Mahmoud Ahmed Abd-Alaaty \\ English Language Teacher
}

Supervised by

Dr. Eman M. A. El-Bashbishy

Professor of Curriculum \& Instruction

$(E F L)$

Faculty of Education, Mansoura University
Dr. Jehan M. El-Bassuony

Assist. Prof. of Curriculum\& Instruction

(EFL)

Faculty of Education, Port-Said University

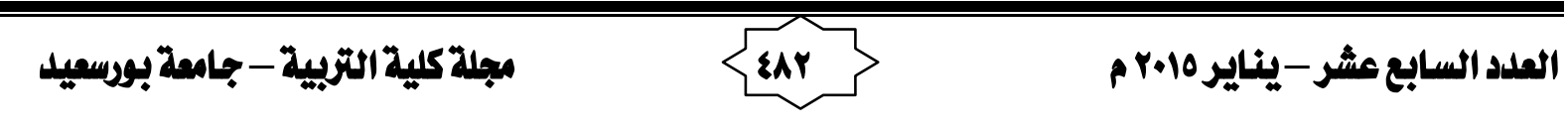




\section{Abstract}

The purpose of this study was to investigate the effectiveness of using thinking maps on the treatment of the EFL grammar difficulties for preparatory stage pupils. Seventy-three second year preparatory stage pupils participated in this study using the pretest-posttest control group design. Two intact classes were randomly assigned to an experimental group $(\mathrm{N}=36)$ and a control group $(\mathrm{N}=37)$. The two groups were pretested to determine the actual performance in grammar.

Data sources consist of: the English grammar diagnostic test and the English grammar difficulties test. The mean score of the experimental group on the pre English grammar difficulties test was compared to their mean score on the post-application of the same test to measure the effectiveness of using thinking maps-based treatment. Findings demonstrated that thinking maps treatment was effective in treating grammar difficulties of EFL second year preparatory stage pupils.

Based on the results obtained, it is concluded that engaging pupils in authentic and constructive learning environment based on using thinking maps, is of significant effect on treating EFL grammar difficulties of second year preparatory stage pupils. The use of thinking maps provides pupils with living learning experiences and real life challenges that enable them to use English for real purposes, explore more with the language, create meaning, construct knowledge, develop skills, and apply concepts. Moreover, using thinking maps allow the cognitive, affective, psychomotor domains to work simultaneously resulting in higher achievement of learning outcomes. Several findings from this study could have implications for further research studies which are necessary to confirm or disconfirm these findings.

Key Words: Thinking Maps and Grammar Difficulties.

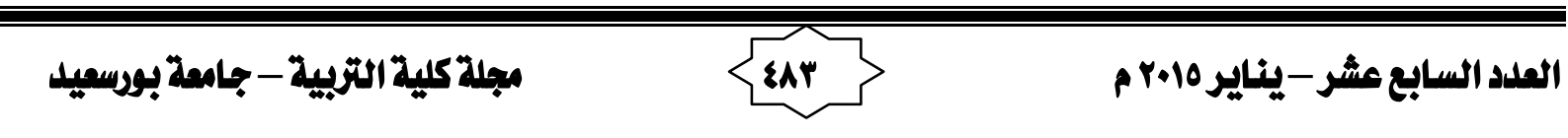




\section{الملخّص}

تعدُّ الكتابة مهارة أكاديمية محورية، فلا يتمكَّن المتعلّم من التفاعُل مع الحياة العلميةّة دون

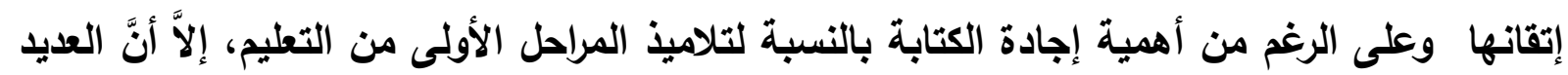

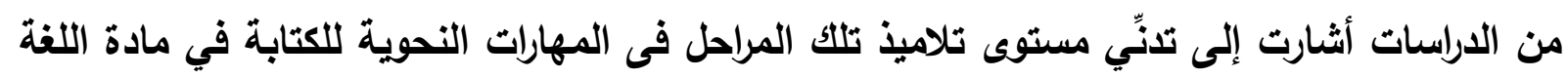

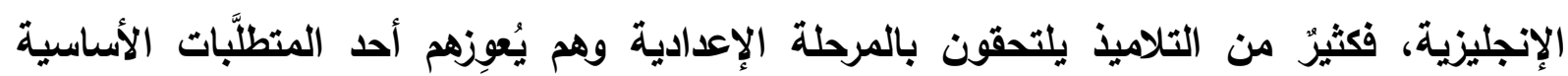

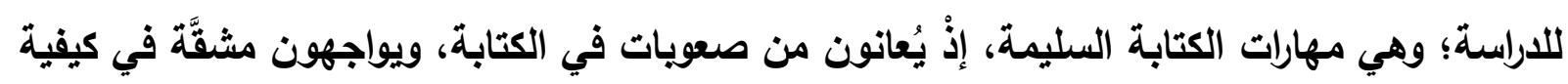

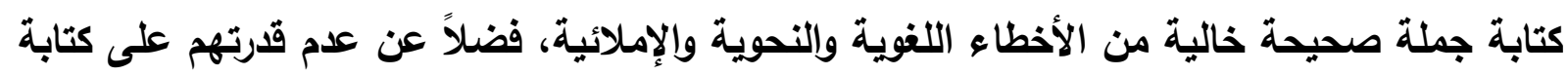

فقرة كاملة مترابطة وصحيحة لغويًا. مشكلة الاراسة:

تكمُن مشكلة الاراسة الحالية فى وجود صعويات فى المهارات النحوية للكتابة في مادة اللغة

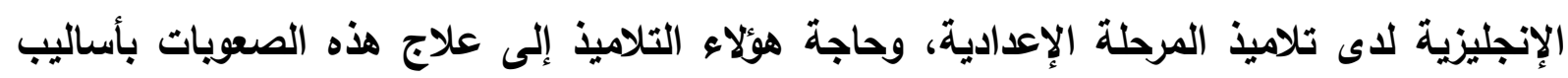

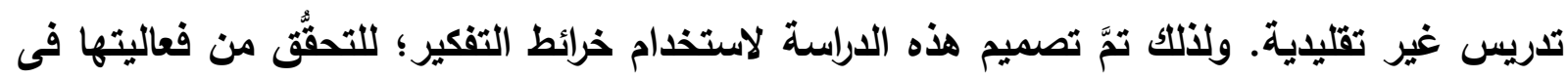
علاج تلك الصعويات. ومن ثم تبلورت مشكلة البحث فى السؤال الرئيس التالي:

ما فاعلية استخدام خرائط التفكير فى علاج الصعويات النحوية في الكتابة لاى تلاميذ المرحلة

$$
\text { إلجراءات الإدراسة: }
$$

تصميم وتطبيق اختبار تثخيصي؛ للكثف عن الصعويات النحوية في الكتابة.

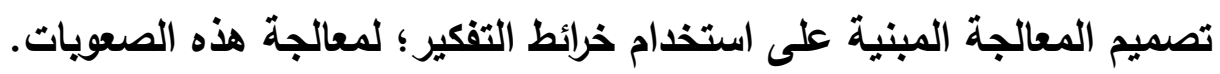

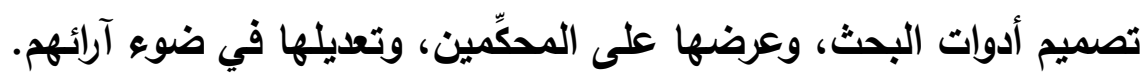

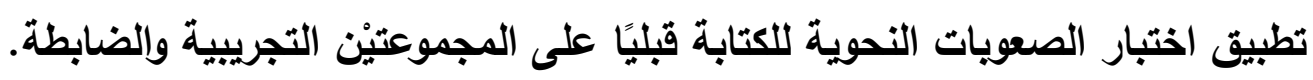
تطبيق المعالجة علي المجموعة التجريبية. تطبيق اختبار الصعويات النحوية للكتابة بعديًا على المجموعتئن التجريبية والضابطة. رصد النتائج، ومعالجتها إحصائيًا، وتفسيرها. تقديم التوصيات والمقترحات. نتائج الاراسة: اعتمادًا على دلالة الفروق الإحصائية بين التطبيقينْ القبلي والبعدي للتلاميذ؛ قد توصَّلت

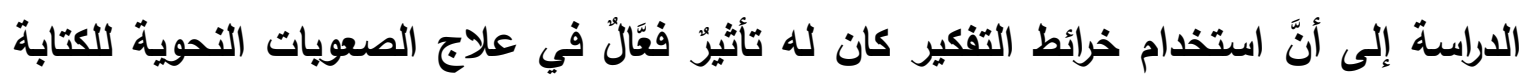
لاى تلاميذ المرحلة الإعدادية. 


\section{Introduction}

The role of grammar instruction in an EFL context has been for decades a major issue for students and teachers alike. Researchers have debated whether grammar should be taught in the classroom and students, for their part, have generally looked upon grammar instruction as a necessary evil at best, and an avoidable burden at worst.

For the most part, within the classroom, any mention of grammar causes the student moments of discomfort and sometimes even terror. Many teachers have tried to make grammar teaching a non-threatening, imaginative and useful activity within the English curriculum. Previous studies on students' and teachers' attitudes and perceptions of grammar instruction in the context of language teaching and learning suggest a disparity between students and teachers (Schultz, 2001; Spratt, 1999).

Some researchers such as (Al Kamil \& Troudi, 2008; Alsamadani, 2010; Myhill, 2005) highlighted the fact that writing is the most difficult skill for Arab students in the field of learning a foreign language due to its complex nature that requires the mastery of a combination of different sub-skills such as the use of grammar, vocabulary, correct spelling, capitalization, punctuation and language points that are usually missed or misused by students.

In fact, mastering all the grammatical points through memorization will be difficult. Memorizing information is not the same thing as actually learning it. The reason for this is that one must understand information to remember it.

In this context, The American Innovative Learning Group has identified Thinking Maps (TMs) as formalized graphic organizers (Hyerle, 1995). Hyerle believes that the principal reason for their success is due to the fact that that they are "a common visual language among students and between students and teachers". TMs combine the task-specific structure of a graphic organizer with the flexibility of a web, enabling the student to transfer thinking processes and develop a common visual language that is shared by other students and teachers (Hyerle \& Curtis, 2001).

Thinking Maps are especially unique because, unlike graphic organizers and webs, maps can be used by teachers to teach lessons, they can be used by students as a learning activity, and they can be used as reflective or developmental learning assessment tools by students and teachers alike. The question then arises: Can TMs truly treat some common EFL grammar difficulties? To be deemed credible, claims must be validated and backed up by proof.

\subsection{Rationale of the study}

In many Arab countries including Egypt, one of the major difficulties in English writing lies in the grammar of the language, which has been found 
to be a major source of writing errors. EFL learners have committed various types of grammatical errors in their written products (Ahmed, 2011; Al-Sharah, 1997; Pongsiriwet, 2001, p. 5).

\subsection{Statement of the problem}

Based on the evidence from reviewing research and the results of the pilot study, conducted by the researcher, the problem of the present study can be stated as follows:

EFL second year preparatory stage pupils seem to have a low level of grammatical performance as a result of the existence of writing mechanical difficulties such as grammar and syntax. Hence, the present study attempted to investigate the effectiveness of using thinking maps on treating these difficulties.

\subsection{Questions of the Study}

More specifically, the present study addresses the following major question:

- What is the effectiveness of using thinking maps in treating EFL grammar difficulties of second year preparatory stage pupils?

To answer the above main question, the following sub-questions drawn to be answered:

1- What are the EFL grammar difficulties of second year preparatory stage pupils?

2- What are the features of a treatment based on thinking maps to treat these EFL grammar difficulties of second year preparatory stage pupils?

3- How far are thinking maps effective in treating these EFL grammar difficulties of second year preparatory stage pupils?

1.4 Hypotheses of the Study

This study attempted to verify the following hypotheses:

1. There is a statistically significant difference between the post-test mean score of the experimental and control groups on the English Grammar difficulties test in favour of the experimental group.

2. There is a statistically significant difference between the pre and posttest mean score of the experimental group on the English grammar difficulties test favoring the post test.

1.5 Purpose of the Study

This study aimed at:

1- Investigating the EFL grammar difficulties for second year preparatory stage pupils by means of a diagnostic test.

2- Determining the most common EFL grammar difficulties for second year preparatory stage pupils.

3- Assessing the effectiveness of using thinking maps on the treatment of the EFL grammar difficulties for preparatory stage pupils. 


\subsection{Significance of the Study}

The current study has the potential to improve English language teachers, learners and educational research in a number of ways:

- It provides an understanding of the most common difficulties faced by preparatory stage pupils in EFL grammar.

- It provides a list of the most common EFL grammar difficulties of second year preparatory stage pupils.

- It provides a teacher's guide of the suggested treatment to guide teachers while using thinking maps in their teaching.

- It also presents a pupil's activity notebook of the suggested units for more learners' practice.

- Using thinking maps research framework could serve as an example for further studies in education and particularly in learning foreign languages.

Adopting a mixed and flexible method research design to treat EFL difficulties which has not been extensively used in Egypt and lays the ground for further research.

\subsection{Review of Literature and Related Studies}

\subsubsection{Grammatical Difficulties}

It is worth making a distinction between two main trends in L2 grammar. On one hand, some researchers conceive grammar in terms of accuracy and error-correction. On the other hand, other researchers perceive grammar as a tool for developing awareness of how linguistic structures shape meaning. With regard to the first view, Truscott (2007) claims that correcting grammatical errors in writing is not helpful and even harmful. In contrast, other researchers view grammar error-correction as beneficial and promoting language development (Bitchener \& Knoch, 2008; Ellis, Sheen, Murakami \& Takashima, 2008).

Learning how to use English grammar is important in language learning. Knowledge and competency of English grammar can help language learners use language effectively and think about how language structures are used to get meaning across (Rodby \& Winterowd, 2005). However, research revealed that grammar teaching does not necessarily support the development of learners' writing (Wyse, 2007). To further investigate this paradox, research studies have been conducted to pinpoint that students are not proficient in English grammar. For example, Mourtaga (2004) conducted a study in which 35 male and 35 female Palestinian freshman students wrote on one of 18 different topics related to the student writers' life and culture. Findings revealed that student' errors in verbs, articles and punctuation, were the most frequent.

In reference to grammatical errors in writing, some research studies have proved that students' grammatical errors are common among

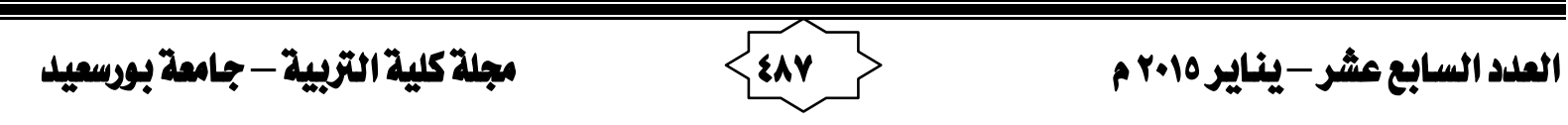


ESL/EFL students' writing. Most importantly is that these studies have suggested using some remedial approaches to help students better understand and use grammar correctly in writing. For example, Abdulla (1995) found out that grammar is taught in a structural manner that is isolated from all language skills. It was also shown that all language skills are taught in separate courses. This justified that the idea of an integrative approach to teaching English in general and writing in particular would be beneficial to Yemini students of English at the university level. To make language learning meaningful, he calls for the integration of grammar and lexis in a piece of discourse as the central unit of learning. Moreover, he believed that language skills must be integrated in learning tasks.

In the same vein, Al-Sharah (1997) who investigated the writing of 210 students studying English at two Jordanian universities, revealed that both bottom-up: linguistic aspects such as words and grammar, and top-down: rhetorical aspects, such as the organization and structure of text, content, and purpose are needed in the writing process.

Also, Pongsiriwet (2001) attempted a study to combine the study of grammatical accuracy with the study of discourse features of second language writing. It was designed to investigate (1) the frequent types of grammatical errors in EFL writing; (2) whether there is a relationship between scores on grammatical accuracy and discourse features of writing; and (3) the effects of grammatical accuracy and discourse features on the evaluation of writing quality. Moreover, Bidin (2004) considered that a discourse-based grammar approach is appropriate for local graduates in Malaysia to a certain extent for improving accuracy and appropriateness of tense usage in $\mathrm{L} 2$ writing.

Similarly, Ahmed (2011) conducted a study with the aim of investigating the essay writing difficulties of Egyptian student teachers of English. Findings of the study revealed that there were eleven focuses of teaching essay writing at the concerned faculty of education. These focuses had been classified into four main categories: Mechanics/Language, Content, Structure/Layout and Practising Writing. Finally, findings showed that student teachers of English encountered the following difficulties in their essay writing: planning difficulties, organisational difficulties including coherence, cohesion, and stylistic difficulties, lexical problems, and technical difficulties including grammar, punctuation, spelling, revision and editing.

The above mentioned research studies give rise to the fact that grammar is a problematic area in the writing of ESL/EFL students. It is also clear that Arab students find grammar a challenging area while composing in English.

\subsubsection{Thinking Maps}

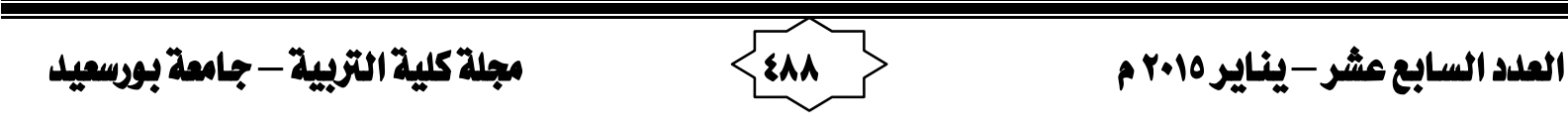


According to Hyerle and Yeager (2000), many of the 12 principles of brain-based learning research summarized by Caine and Caine (1997) support the use of TMs and provide a theoretical basis for thinking maps use. The maps give students a concrete way to see abstract ideas. Students first use each map in personal ways with their own information, thus hooking them emotionally. These initial personal experiences and successes with the maps allow students not to feel threatened when used later for deeper thinking. The maps provide meaning because they are repeated consistent patterns with each pictured thought process reinforced with the vocabulary of that thought process and the student's previous usage of the map.

The repeated use of these specific maps as a way to integrate and retain knowledge in permanent memory was supported by research from Marzano (2003, p. 112) who stated "multiple exposures to knowledge are required to integrate and retain knowledge in permanent memory." According to Hyerle and Yeager, once the maps have been taught to students, the brain unconsciously pays attention to the eight thought processes. When the brain pays attention to information that has emotion or meaning, it attempts to store that information in short-term memory (Kotulak, 1996). However, in order for information to be stored in longterm memory, an individual must process the material (Danielson, 2002).

Actually, many studies have been conducted for the use of thinking maps such as (Blount, 1998; Hindman, 2000; Curtis, 2001). Blount examined the reading comprehension of underachieving fourth grade students in an inner city school and determined that TMs use indicated improvement in reading comprehension. In addition, Hindman examined 1,000 students and determined that more than half used a visual tool during test taking.

Moreover, Curtis used interviews, teacher and student documents, and surveys to show how TMs training and follow-up training directly supported teacher thinking and reflection. In addition, Ball (1998) found a highly significant correlation between the use of TMs and reading comprehension scores of college students using the Stanford Diagnostic Reading Test as the evaluating instrument.

From the same point of view, Buckner (2000) developed WFtB (Write.... From the Beginning) from her own synthesis of writing research as well as twenty-five years of explorations and observations of the most effective methods for teaching writing to elementary students. Fundamentally, WFtB extends and complements TMs by providing more elaborated approaches to teaching writing from a developmental perspective, as children move in stages consistent with Piagetian ideas of cognitive development. As children become more proficient writers, WFtB

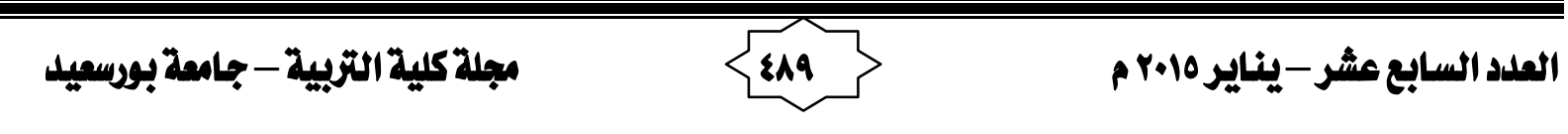


instruction provides teachers with appropriate tasks and assessment strategies to enhance their composition, mechanics and fluency.

\subsection{Delimitations of the Study}

The proposed study was limited to the following:

1- Two intact classes from the second year, Mogam'a Bany Ebade Preparatory School, Dakahlia Governorate.

2- $\quad$ Thinking maps as an instructional model.

3- The grammar difficulties specified by the English grammar diagnostic test.

4- The time frame for this study was limited to ten weeks, two sessions ( 4 periods) per week.

\subsection{Definitions of the Study Terms:}

According to the context of the current study, the researcher made use of the following terms:

\section{Thinking Maps:}

According to Hyerle, Suddreth \& Suddreth (2004) thinking maps are a specific set of eight formal graphic organizers that are designed to simulate eight specific thinking processes, including defining, describing, compare and contrast, cause and effect, sequences, part to whole relationships, classification, and analogies.

Based on the previous definition, an operational definition for the present study could be adopted. Thinking maps, therefore, refers to a specific brand of graphic organizers that have eight specific maps that define words, describe ideas, compare and contrast, show relationships, shows events as sequence, cause and effect, part-whole relationships, and creates analogies. The intervention used in this study incorporated all eight maps to treat the most grammar difficulties for EFL learners in the preparatory stage.

1.10 Methodology

\section{Participants}

The study targeted second year preparatory pupils (73 pupils) at Mogam'a Bany Ebade Preparatory School, Dakahlia Governorate in the first semester of the academic year 2013/2014. Their age ranged from 13 to 14 years old. Two classes were selected and assigned at random to an experimental group $(\mathrm{N}=36)$, and a control group $(\mathrm{N}=37)$. All participants had the same schooling background.

\section{Duration}

The experiment was administered during the first term of the academic year (2013-2014) during October, November and December. It lasted for about 10 weeks, two sessions (4periods) every week. Each period lasted for 40 minutes.

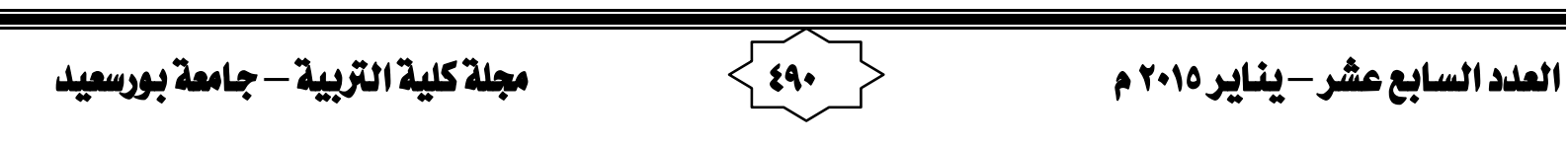




\section{Design}

The present study adopted the quasi-experimental design, two intact classes were randomly assigned to an experimental group $(\mathrm{N}=36)$ and a control group $(\mathrm{N}=37)$. The two groups were pretested to determine the actual performance in writing. The participants' mean score on the pre-test were compared with their mean scores on the post-test; and the experimental group mean scores on the pre-application of The English writing difficulties test was compared to their mean score on the postapplication of the same test to measure the effectiveness of the proposed thinking maps-based treatment.

\section{Instruments}

The following instruments were all designed by the researcher and used throughout the research:

1- The English Grammar Diagnostic Test (EGDT).

2- The English Grammar Difficulties Test.

\subsubsection{English Grammar Diagnostic Test (EGDT):}

Before conducting the EGDT, a pilot study was administered to $(n=$ 24) pupils in the second year preparatory stage. Its purpose was to test and develop the adequacy of the English Grammar Diagnostic Test and to assess its time and reliability.

Rationale and Objectives of the Test

The English Grammar Diagnostic Test was designed to diagnose the preparatory pupils' points of strength and weakness in their grammar as learners of English as a foreign language. In addition, the diagnostic test was used to identify the nature of the needed instruction and to determine areas that needed attention to consider in developing the proposed treatment.

\section{- $\quad$ Test Validity}

For estimating the content validity of the English Grammar Diagnostic Test (EGDT), the test was presented to thirteen TEFL specialists to evaluate the test in terms of clarity of its items and directions as well as the suitability of the test items for the pupils' level. The jurors generally approved the items of the test. Some changes were suggested and certain modifications have been made to the test.

\section{Test Reliability}

In order to establish the reliability of the test, Cronbach's alpha was used. The value of alpha coefficient was $(0.95)$. This means that the test was reliable. So, it was applicable in its final copy.

To ensure the validity of the EGDT, the self/intrinsic validity of the test was statistically estimated by calculating the Root Square of the reliability coefficient. Since the reliability coefficient of the EWDT was ( $r=$ 
Using Thinking Maps in the Treatment of EFL Grammar Difficulties for Preparatory Stage Pupils Hisham Mahmoud Ahmed Abd-Alaaty 0.95), its selt/intrinsic valídity was (0.97). Statistically speaking the EGDT was valid and reliable.

To calculate the percentage of each difficulty, the researcher used the following equation:

The percentage of a common difficulty $=\frac{\text { the recurrence of the difficulty }}{\text { the total no of pupils }} \times 100$

A difficulty is considered common when a group of pupils $\geq 25 \%$ of the total number of Pupils $(n=41)$ has marks $\leq 25 \%$ of the mean ratio of the test mark (Gebril, 2010, p.88).

The results indicate that the following grammatical points represent real difficulties due to their percentage of recurrence among pupils. These points are: the use of tenses, auxiliary, subject-verb agreement, use of verbs, adjectives, adverbs, preposition, conjunctions and syntax.

\subsubsection{The English Grammar Difficulties Test}

The English Grammar Difficulties pre-posttest was developed to investigate the effectiveness of the suggested treatment after specifying the most common grammar difficulties among the second year preparatory stage pupils by applying the (EGDT) and analyzing its results. The test is administered to both groups, control and experimental, before applying the treatment to make sure that pupils of both groups were at the same level, and hence the progress achieved by the experimental group could be attributed to the treatment they had been exposed to.

Test Validity

For estimating the content validity of the English Grammar Difficulties Test, the test was presented to thirteen TEFL specialists to evaluate the test in terms of clarity of its items and directions as well as the suitability of the test items for the pupils' level. The test proved to be valid as the jurors approved all of its questions and items.

Test Reliability

In order to establish the reliability of the test, Cronbach's alpha formula was used. The calculated reliability coefficient was $(0.92)$ which indicated the high internal consistency of the test. Thus, the EFL Grammar Difficulties test is reliable to be used.

To ensure the validity of the English Grammar Difficulties Test, the self-validity of the test was statistically estimated by calculating the root square of the reliability coefficient. Since the reliability coefficient of the English Grammar Difficulties Test was $(\mathbf{r}=\mathbf{0 . 9 2})$, its self-validity was (0.96). Statistically speaking the test was valid and reliable.

\subsubsection{The Treatment}

Description of the Treatment:

- The pre-application of the English Grammar Difficulties Test:

This test was administered to 73 pupils $($ Exp. $=36 \&$ Control=37) in the second year preparatory stage. Its purpose was to make sure that both

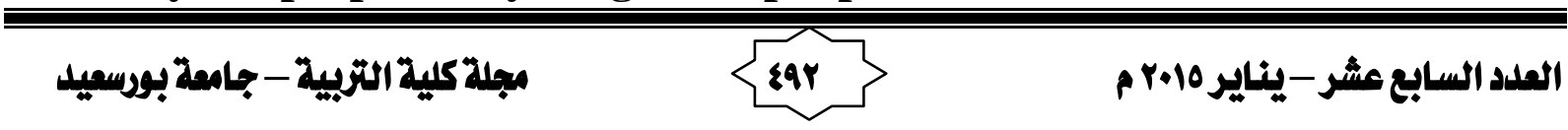


groups, the experimental and the control groups, were homogeneous.

- The experimental treatment:

The experimental group $(n=36)$ was taught to treat the targeted difficulties, improve and develop the level of their EFL grammar via the use of thinking maps, while the control group $(n=37)$ was taught in the traditional method of teaching. Both groups were taught by the researcher.

- The post- application of the English Writing Difficulties Test:

The post application of this test was administered after the experimental treatment to the same 73 pupils $($ Exp. $=36 \&$ Control=37). It aimed at revealing the changes in the pupils' level of improvement in EFL grammar to measure the effectiveness of the proposed treatment of using thinking maps in treating the grammar difficulties of the second year preparatory stage.

\subsection{Results and Discussion}

\subsubsection{Results}

To measure the difference between the experimental and control groups on both the pretest and posttest, the participants' scores were statistically analyzed using the t-test formula. Also, $F$ test was used to compare the two variances of the experimental and control groups in the post application of the English Grammar Difficulties Test. Moreover, LSD (Least Significant Difference) test was used to compute a standard error of the difference or the smallest significant difference between the means of the experimental and control groups in the post application of the English writing Difficulties Test. Finally, Eta squared value $\left(\eta^{2}\right)$ was used to measure the effect size of the experimental treatment on EFL grammar difficulties of the second preparatory pupils. The following shows these results:

\section{- Preliminary Analysis}

To make sure of the equivalence of the subjects of the study and to measure whether there was a statistically significant difference between the pre-test mean scores of the experimental and control groups on the English Grammar Difficulties Test; means, standard deviation, and $t$ - test values were calculated and the results obtained are shown as follows:

Table 1.1 The $t$-test Value for the Mean Difference between the Experimental and Control Groups on the Pre English Grammar Difficulties Test

\begin{tabular}{|c|c|c|c|c|c|c|c|c|c|c|c|}
\hline \multirow{2}{*}{ Skills } & \multirow{2}{*}{ Groups } & \multirow{2}{*}{ Mean } & \multirow{2}{*}{$\begin{array}{l}\text { Std. } \\
\text { Deviatio } \\
\text { n }\end{array}$} & \multicolumn{3}{|c|}{$\begin{array}{l}\text { Levene's Test for Equality } \\
\text { of Variances }\end{array}$} & \multicolumn{5}{|c|}{ t-test for Equality of Means } \\
\hline & & & & $\mathbf{F}$ & Sig. & $\begin{array}{l}\text { Equal } \\
\text { variances }\end{array}$ & $\mathbf{t}$ & df & Sig. & & $\begin{array}{l}\text { Equal } \\
\text { Means }\end{array}$ \\
\hline \multirow{2}{*}{$\begin{array}{l}\text { Grammatical } \\
\text { Difficulties }\end{array}$} & Cont. & 14.432 & $\begin{array}{l}8.0296 \\
0\end{array}$ & \multirow{2}{*}{$\begin{array}{l}.01 \\
3\end{array}$} & \multirow{2}{*}{.908} & \multirow{2}{*}{ assumed } & \multirow{2}{*}{-} & \multirow{2}{*}{$\begin{array}{l}7 \\
1\end{array}$} & \multirow{2}{*}{.09 } & \multirow{2}{*}{$\begin{array}{l}> \\
0.05\end{array}$} & \multirow{2}{*}{$\begin{array}{l}\text { assume } \\
\text { d }\end{array}$} \\
\hline & Exp. & 17.680 & $\begin{array}{l}8.2489 \\
4\end{array}$ & & & & & & & & \\
\hline
\end{tabular}

مجلة كلية التربية - جامعة بورسيديد

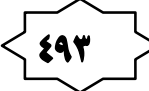

العلد السابع عشر - يناير 10. م م 
Using Thinking Maps in the Treatment of EFL Grammar Difficulties for Preparatory Stage Pupils Hisham Mahmoud Ahmed Abd-Alaaty

As shown in table 1.1 the t-test for independent samples shows that the t-value for the pre English Grammar Difficulties Test is not significant at the 0.05 level. So, the researcher will use the " $F$ " test to compare the variances of the experimental and control groups in the post application of the English Writing Difficulties Test.

F value was calculated to compare the two variances of the experimental and control groups in the post application of the English Grammar Difficulties Test. The $F$ values were calculated as listed in the following table:

Table 1.2 The $F$ test values for the two Means of the experimental and control groups in the post application of the English Grammar Difficulties Test

\begin{tabular}{|l|l|l|l|l|l|l|l|}
\hline \multirow{3}{*}{ Skills } & Source & $\begin{array}{l}\text { Type III Sum of } \\
\text { Squares }\end{array}$ & df & Mean Square & F & Sig. \\
\hline \multirow{4}{*}{$\begin{array}{l}\text { Grammatical } \\
\text { Difficulties }\end{array}$} & pre-test & 2959.763 & 1 & 2959.763 & 233.356 & .000 \\
\cline { 2 - 8 } & post-test & 2111.795 & 1 & 2111.795 & 166.500 & .000 \\
\cline { 2 - 8 } & Error & $\mathbf{8 8 7 . 8 4 3}$ & 70 & 12.683 & & \\
\cline { 2 - 8 } & $\begin{array}{l}\text { Corrected } \\
\text { Total }\end{array}$ & 7199.171 & 72 & & & \\
\hline
\end{tabular}

As shown in table 1.2 the $F$ values are significant at the 0.01 level. It means that there are differences between the experimental and control groups in the post English Grammar Difficulties Test. Then, the researcher used the LSD Test (Least Significant Difference) to find out the standard error of the difference between the experimental and control groups in the post English Grammar Difficulties Test and to indicate which group differs. Table 1.3 The LSD test values for the two Means of the experimental and control groups in the post English Grammar Difficulties Test

\begin{tabular}{|l|l|l|l|l|l|l|l|}
\hline Skills & Groups & Mean & $\begin{array}{l}\text { Std. } \\
\text { Deviation }\end{array}$ & N & $\begin{array}{l}\text { Estimated } \\
\text { Marginal } \\
\text { Means }\end{array}$ & $\begin{array}{l}\text { Mean } \\
\text { Difference } \\
\text { (I-J) }\end{array}$ & Sig. \\
\hline $\begin{array}{l}\text { Grammatical } \\
\text { Difficulties }\end{array}$ & Exp. & $\mathbf{6 . 9 1 6 7}$ & $\mathbf{2 . 4 0 0 8 9}$ & $\mathbf{3 6}$ & $\mathbf{6 . 4 2 2}$ & $\mathbf{3 . 3 5 9}$ & $\mathbf{. 0 0 0}$ \\
\cline { 2 - 8 }
\end{tabular}

As shown in table 1.3 the LSD values are significant at the 0.01 level in the post English Grammar Difficulties Test favoring the experimental group.

Then the $t$-test for dependent samples was used to compare the Mean Scores of the experimental group on both the English Grammar Difficulties pre and post tests.

Table 1.4 The $t$-test value for the two Mean Difference on both the Pre and Post Tests Scores on the English Grammar Difficulties Test

\begin{tabular}{|l|l|l|l|l|l|l|l|l|l|}
\hline Skills & $\mathrm{N}$ & test & Mean & $\begin{array}{l}\text { Std. } \\
\text { Deviation }\end{array}$ & Correlation & Sig. & $\mathrm{t}$ & df & Sig. \\
\hline $\begin{array}{l}\text { Grammatical } \\
\text { Difficulties }\end{array}$ & \multirow{3}{*}{36} & pre & $\mathbf{1 7 . 6 8 0 6}$ & $\mathbf{8 . 2 4 8 9 4}$ & $\mathbf{. 8 2 2}$ & $\mathbf{. 0 0 0}$ & -14.341 & 35 & $\mathbf{. 0 0 0}$ \\
\cline { 3 - 10 } & & post & $\mathbf{2 8 . 9 5 8 3}$ & $\mathbf{6 . 3 2 9 4 9}$ & & & \\
\hline
\end{tabular}


Results in table 1.4 show that the participants' mean score on the Pre

EFL grammar difficulties test is (17.68); while their mean score on the Post Test is (28.59). The $t$-test value of the pre and post test is (14.34) is statistically significant at the (0.01) level in favor of the post test. This shows that the grammar difficulties of the experimental group have improved after the exposure to the treatment. This finding indicates that the improvement achieved can be attributed to the effect of using thinking maps in the treatment of the EFL grammar difficulties.

\section{Calculating Effect Size}

The following table presents the effect size of thinking maps on treating EFL grammar difficulties. From the results obtained in table 4.5, it can be concluded that the size effect of the treatment on the pupils' grammar difficulties is very large as it is more than (.50).

Table 1.5 Effect Size $(\eta 2)$ Values of using thinking maps on EFL grammar difficulties

\begin{tabular}{|c|c|c|c|c|c|}
\hline Skills & $\mathbf{N}$ & $\begin{array}{l}\text { Tes } \\
\text { t }\end{array}$ & $\begin{array}{l}\text { Mea } \\
n\end{array}$ & $\eta 2$ & $\begin{array}{l}\text { Effect } \\
\text { Size }\end{array}$ \\
\hline \multirow{2}{*}{$\begin{array}{l}\text { Grammar } \\
\text { Difficulties }\end{array}$} & \multirow{2}{*}{$\begin{array}{l}3 \\
6\end{array}$} & pre & 17.68 & \multirow{2}{*}{$\begin{array}{l}0.8 \\
5\end{array}$} & \multirow[b]{2}{*}{ High } \\
\hline & & pos & 28.95 & & \\
\hline
\end{tabular}

Results in table 1.5 show that Eta squared values for EFL grammar difficulties test $(\mathbf{0 . 8 5})$ is highly significant. This indicates that the experimental treatment is effective in treating the EFL grammar difficulties.

\subsubsection{Discussion of the Results:}

In this section, the results will be discussed and interpreted in light of the theoretical background and other results reported by the related studies.

\section{Diagnostic Test}

Firstly, the findings of the diagnostic test were not surprising. Results indicated that pupils lack some grammatical difficulties. Such findings have serious implications and put the pupils at risk for academic failure. Thus, such findings point to the growing need of effective and unique way of treating these difficulties in an early stage.

- Effects of Thinking Maps on Treating EFL Grammar

\section{Difficulties}

The t-test showed that there was a significant difference at the 0.01 level favoring the experiment group. This finding implies that the use of TMs proved effectiveness in improving EFL grammatical performance. The significant improvement achieved by the experimental group can be attributed to the best use of thinking maps via the following: 
Firstly, providing a theoretical basis for the use of thinking maps and training the pupils well. As a result, the maps give the pupils a concrete way to see abstract ideas. This finding is consistent with Hyerle and Yeager (2000). Also, the repeated use of these specific maps was a good way to integrate and retain knowledge in permanent memory as well as storing that information for a long time. This finding is consistent with (Kotulak, 1996) and (Marzano, 2003).

Furthermore, using thinking maps supported patterning, organizing and networking pupils' information into knowledge and supported searching for meaning within prior knowledge. This finding is consistent with (Hyerle, 1996). Moreover, thinking maps have specific features that facilitate different structural forms of writing, as well as comprehending text of different genres and purposes. Each map also allowed the linking of isolated bits of information into holistic systems. This finding is consistent with (Hyerle, 1995).

Being consistent, integrative, reflective, developmental and flexible, thinking maps have shown considerable improvement in the pupils' performance and have improved test scores. This finding is consistent with (Hyerle, 1995), (Hyerle and Yeager, 2000) and (Hyerle, 2000).

Finally, unlike previous research that has shown that thinking maps have been effective with native learners and sometimes with second language learners only, this study proved clearly the effectiveness of using thinking maps with EFL learners.

\subsection{Recommendations}

Based on the findings obtained from the present study, the following recommendations could be offered:

- EFL Curriculum designers and developers should plan to incorporate thinking maps in TEFL curriculum. This helps provide pupils with authentic learning environment through which learning outcomes can be achieved; knowledge can be gained, skills can be acquired, and attitudes can be enhanced.

- $\quad$ Future educational policy should adopt promising pedagogical paradigms based on using thinking maps.

- $\quad$ Teachers of EFL should teach thinking maps with the following procedures in mind: (a) provide explicit strategy instruction, (b) demonstrate the strategy and model the metacognition necessary for carrying out the strategy, (c) provide opportunities for specific feedback, and (d) allow sufficient time for practice to achieve mastery of the strategy.

- Thinking Maps should be a life style method of thinking and learning which is practiced by all pupils and students from the primary stage to the university one. So, an attractive activity book 
Using Thinking Maps in the Treatment of EFL Grammar Difficulties for Preparatory Stage Pupils Hisham Mahmoud Ahmed Abd-Alaaty with simple thinking maps models or templates are of great necessary if taught to the primary stage pupils.

\subsection{Suggestions for Further Research}

- $\quad$ Future research is needed to measure the effectiveness of using thinking maps in enhancing other areas of EFL learning such as reading and writing.

- Also, it would be informative to evaluate using thinking maps with EFL younger and older learners (i.e. primary, secondary and university students).

- Further research is needed to explore the extent to which thinking maps-based learning can meet both the content standards of English language stated by both National Authority for Quality Assurance and Accreditation of Education (NAQAAE) and Ministry of Education (MOE).

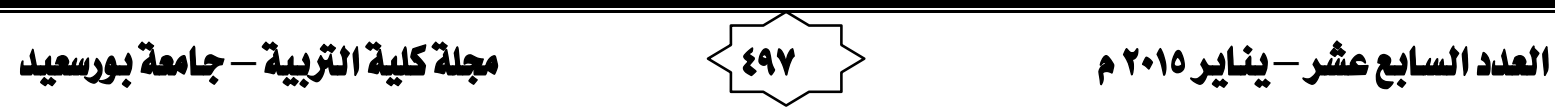




\section{References}

1. Abdulla, F. (1995). An integrated approach to writing English in the University of Aden, Yemen. Unpublished doctoral dissertation, University of Manchester, UK.

2. Ahmed, A. (2011). The EFL Essay Writing Difficulties of Egyptian Student Teachers of English: Implications for Essay Writing Curriculum and Instruction. Unpublished doctoral dissertation, Exeter University.

3. Al Kamil, I., \& Troudi, S. (2008). Can theory help us understand the nature of writing challenges? In Coombe C., Jendli A., Davidson P.Teaching Writing Skills in EFL: Theory, Research and Pedagogy (pp. 3-15). Dubai: TESOL Arabia Publications.

4. Alsamadani, H. (2010). The Relationship between Saudi EFL Students' Writing Competence, L1 Writing Proficiency, and Selfregulation. European Journal of Social Sciences, 16 (1).

5. Al-Sharah, N. (1997). An investigation of EFL student writing: aspects of process and product. Unpublished doctoral dissertation, University of Glasgow, UK.

6. Ball, M.K. (1998). The effects of thinking maps on reading scores of traditional and nontraditional college students. Unpublished doctoral dissertation, The University of Southern Mississippi, Hattiesburg, MS.

7. Bidin, S. (2004). The effect of discourse-based grammar teaching on second language learning: the case of tense usage. Unpublished doctoral dissertation, University of Nottingham, UK.

8. Bitchener, J. \& Knoch, U. (2008). The value of written corrective feedback for migrant and international students. Language Teaching Research, 12, 409- 431.

9. Blount, M. H. (1998). The effects of Thinking Maps ${ }^{\circledR}$ on reading retention. Retrieved Feb. 20, 2012, from http://www.mapthemind.com.

10. Buckner, J. (2000) Write...from the Beginning K-5. Raleigh, NC: Innovative Learning Group.

11. Caine, G., \& Caine, R. (1997). Education on the edge of possibility. Arlington, VA: Association for Supervision and Curriculum Development.

12. Curtis, S. (2001). Inviting explicit thinking: thinking maps professional development. Retrieved Feb. 22, 2012, from http://www.mapthemind.com. 
13. Danielson, C. (2002). Enhancing student achievement: a framework for school improvement. Alexandria, VA: Association for Supervision and Curriculum Development.

14. Ellis , R., Sheen , Y. , Murakami , M. , \& Takashima , H. ( 2008 ). The effects of focused and unfocused written corrective feedback in an English as a foreign language context. System, 36, 353 - 371.

15. Gebril, M. (2010). A Proposed Constructivism Based Program for Remedying some Linguistic Errors and Reducing Writing Anxiety of the Secondary Stage Students. Unpublished master thesis, Faculty of Education, Mansoura University.

16. Hindman, J. L. (2000). Are middle school students using Thinking Maps ${ }^{\circledR}$ in writing? Retrieved July 20, 2012, from http://www.mapthemind.com.

17. Hyerle, D. (1995). Thinking Maps ${ }^{\circledR}$ tools for learning.Raleigh, NC: Innovative Services.

18. Hyerle, D. (1996). Visual tools for constructing knowledge. Alexandria, VA: Association for Supervision and Curriculum Development.

19. Hyerle, D. (2000). A Field guide to using visual tools. Alexandria, VA: Association for Supervision and Curriculum Development.

20. Hyerle, D. \& Curtis, S. (2001). Thinking maps training. Training session conducted at the Innovative Learning Group conference, Nashua, NH.

21. Hyerle, D., Suddreth, S., Suddreth, G. (2004-2008). Thinking Maps. Retrieved November 18, 2012, from http://www.thinkingmaps.com

22. Hyerle, D., \& Yeager, C. (2000). Thinking Maps ${ }^{\circledR}$ training of trainers guide resource manual (Rev. ed.). Raleigh, NC: Innovative Services.

23. Kotulak, R. (1996). Inside the brain: Revolutionary discoveries of how the mind works. Kansas City, MO: Andrews McMeel.

24. Leki, I. (2000). Writing, literacy, and applied linguistics. Annual Review of Applied Linguistics, 20, 99-115.

25. Marzano, R. J. (2003). What works in schools: Translating research into action. Alexandria,VA: Association for Supervision and Curriculum Development.

26. Mourtaga, K. (2004). Investigating writing problems among Palestinian students studying English as a foreign language. Dissertation Abstracts International, 66 (1), 63.

27. Myhill, D. (2005). Prior knowledge and the (re)production of school written genres: An Analysis of British Children's Meaning-making Resources. In Kostouli T. Writing in Context(s): Textual Practices and Learning Processes in Sociocultural Settings. USA: Springer. 
28. Myhill, D. (2005). Ways of knowing: Writing with grammar in mind. English Teaching: Practice and Critique, 4(3), 77-96.

29. Pongsiriwet, Ch. (2001). Relationships Among Grammatical Accuracy Features, and the Quality of Second Language Writing: The Case of Thai Learners. Unpublished doctoral dissertation. West Virginia University.

30. Rodby, J., \& Winterowd, W. (2005). The Uses of Grammar. New York: Oxford University Press.

31. Truscott, J. (2007). The effect of error correction on learners' ability to write accurately. Journal of Second Language Writing 16, 255-272.

32. Schultz, R. (2001). Cultural differences in student and teacher perceptions

33. concerning the role of grammar instruction and corrective feedback. USA-Colombia. The Modern Language Journal, 85(ii): 244-258.

34. Spratt, M. (1999). How good are we at knowing what learners like? System, 27:141-155.

35. Wyse, B. (2007). The Teaching of English: Research Evidence and Government Policy. Unpublished doctoral dissertation, University of Liverpool John Moores, UK. 